\begin{tabular}{l|l} 
& $\begin{array}{l}\text { Eastern } \\
\text { European } \\
\text { Countryside }\end{array}$ \\
\hline DOI: $10.2478 /$ eec-2014-0001 & $20^{\prime} 2014$
\end{tabular}

Krzysztof Gorlach, Marta Klekotko, Piotr Nowak

\title{
Culture and Rural Development: Voices from Poland ${ }^{1}$
}

\begin{abstract}
The paper is focused on the issue of culture and its connections to rural developments. It was based on the assumption that the culture has various impacts on rural communities' life, as well as, it has been present in various ways in functioning and changes that might be observed in rural areas. In our opinion, such a perspective should be presented in a more detailed way in order to stress the multiple and various impact of cultural issues on economic and social transformations in rural areas. Therefore, we divided our paper into three consecutive parts. In the first one, we discussed the multi-dimensional image of culture, and its role in human development. In the second one, we discussed some changes in the mechanisms of rural development, perceived as moving from the traditional to the contemporary one. We wanted to stress that culture seems to be an important part of the latter one. The last part of our considerations brought some empirical evidence from Poland focused on the role of culture in rural developments showing, at the same type, some examples of this new mechanism of rural development.

1 This paper is an elaborated copy of an earlier draft presented at the international conference on "Social and Economic Transformations Affecting People and Rural Communities in Central and Eastern Europe since 1990" held at the Slovak University of Agriculture in Nitra, Slovakia, September 2-3, 2013. The authors want to thank Professor Joachim Singelmann (University of Texas, San Antonio, USA) for his helpful and inspiring comments on an earlier draft of this paper.
\end{abstract}


Keywords: rural development, multi-dimensional image of culture, traditional vs. contemporary rural development

\section{Culture and Human Development: Some Analytical and Theoretical Remarks}

Considerations about the issue of culture in social sciences have been framed by two different approaches: global and selective ones (see; for example,: Kłoskowska, 1983). In the first, sometimes named as an anthropological, the culture has been compared with all the types of human activities, as well as, their results. In turn, in the second one, sometimes referred to as a pure sociological, the concept of culture has been limited to the area of symbols, connected to other spheres of social life, namely: economy and politics. These two approaches have been framed into the issues of social change or social/human development. According the first approach, social change and/or development has been understood simply as changes of totally perceived culture, i.e. observed in many aspects of social life. The second approach has to be perceived as a different one. In this particular case, some peculiar relations between culture and economy, as well as, politics might form various constellations. One might elaborate culture as a kind of "environment" in which economic and political processes seem to be embedded (see for example: Granovetter 1985). In the other case, the culture might be treated as a kind of a "braking mechanism" of some economic, as well as, political processes, resulting in retarded social reactions (see: for example, Ogburn, 1975).

Such two approaches seem to be characteristic of rather traditional way of thinking about social change and/or development. In our opinion, both of them frame the culture as a so-called secondary issue of social changes. A social change has been resulting mainly in technical and economic changes where social and cultural developments seemed to be only the reflection of the former ones. However, in this paper, we wanted to treat culture in a definitely opposite way. We treated it as an important, as well as, primary issue in the processes of human development. We formed our approach on the assumption that; in contemporary times, the role and significance of culture in the dynamics of social life have been changed in an important way. This new perspective has been framed by the concept of the so-called "cultural turn". This particular approach stressed a kind of 
a relative autonomy of culture in contemporary society and it has focused on various aspects of heavy impact of culture on various spheres of social life (see, for example: Ray and Sayer, 1999).

Based on such an assumption, several significant relations between culture and a social change/development have to be focused on and analyzed. Starting from the very beginning, one might perceive culture as a kind of legacy. Moreover, culture might be conceptualized as a modernity, as an instrument of modernity, as developmental assets, as politics, as a mechanism of development, as an industry, as a power, as an instrument of liberation and empowerment, a part of human rights, a right to present its own identity, as well as, a discourse.

Under the frame of modernization theories, culture has been treated as a set of values, attitudes, as well as, institutions that formed a kind of historical legacy and, at the same time, a point of departure for modernization processes. This initial stage, sometimes called as traditional and/or premodern society, in the history of social science and sociology, has been contradicted with modernity that means particular values, institutions, attitudes and patterns of behavior, that were characteristic of modern i.e. developed, Western societies (culture as modernity). Theories of modernization have been mostly based on the assumptions of universal, linear, periodical, and convergent character of developmental processes. Under such a perspective, Western societies have been perceived as a kind of the normative pattern, as the most advanced stage of human development, as a kind of the final goal that has to be approached by every other type of society all over the world. The basic assumption in such a line of argument has been based on the assumption that the so-called indigenous structures and patterns would have been replaced by the "modern" (Western) ones. Indigenous (traditional, pre-modern) values and institutions have been treated as a kind of obstacle on the way of development, mainly perceived as an economic growth (see: Rostow 1960). Therefore, the cultural change has been treated as a pre-condition for economic development (Mayo 2000: 89).

Based on the assumption that the cultural changes have to be treated as a pre-condition for human development, some characteristics of traditional (pre-modern), as well as, modern societies have been multiplied. In such a case, the culture (Western, modern type) has been conceptualized as a strategy of modernization. In order to formulate and implement such sets 
of values, both traditional means of communication, as well as, the modern media have been mobilized. Educational institutions, other elements of culture and arts have been used. The best examples of such efforts might be the cases from various societies of the so-called the Third World where such modernizing messages have been present in the stories performed by local theatres. In such cases, modern farming tools or hygienic behaviors have been presented as educational goals, as some messages teaching "proper" types of behavior among indigenous populations.

It is easy to say that cultural legacy might be supportive to the developmental processes, as well as, protestant religion might be supportive to the emergence of capitalism (Weber 1994). Therefore, in many ideas of human development, starting from the endogenous development perspective, treated as a modernization paradigm (Krzysztofek and Szczepański 2002), the culture has been perceived as a kind of developmental resource legacies. In such a perspective, culture has been presented in various types, namely as: communities ' empowerment, neo-endogenous development, building of the local potential, as well as, a sustainable development. Social and cultural assets, usually framed in such a discourse as social and cultural capitals, have formed a starting point for local community development. One of the Polish sociologists defines cultural capital in local community as: "[...] an effect of cumulating of peculiar as well as representative types of symbolic culture, stressing its peculiarity as well as framing patterns of social behavior, their motivations and ways of symbolic communication among social groups" (Świątkiewicz 2000: 34). In this concept, eight types of cultural assets in local communities have been identified, namely: 1/ educational infrastructure, 2/ occupational structure; 3/ language component in a particular group; $4 /$ homogeneity vs. heterogeneity existing inside of a particular community; 5 / institutionalization of values as well as community infrastructure; 6/ social structure and mobility; $7 /$ folklore and its social scope; 8/ scopes of cultural changes and innovations (Świątkiewicz 2000: 35).

A particular type of cultural resources results from cultural policies performed in local communities (see: Klekotko 2012). However, contemporary tasks of cultural policies seem to be located beyond the sphere of culture as such. Cultural policies form "[...] an important part of various local economic policies, that weaken negative results of transfer from industrial to post-industrial economy" (Bradley and Hall 2006: 79). 
In such a context, culture has become a tool to achieve some social goals. It might be also treated as a part of the so-called social engineering. Using some amusements, as well as, sport activities, local communities might achieve their developmental goals. Such strategies have contained some social and economic goals as well, namely: elimination of unemployment as well as marginalization and social exclusion. Community empowerment seems to be also another kind of such a strategy. Moreover, one might point out that culture and amusement have formed some kind of background in order to put closer various types of individuals and social groups, as well as, strengthen social inclusions (Evans and Foord 2006: 152).

Another issue focused our interest on the next dimension of culture, namely: culture as power. As one of the leading Polish sociologists, Stefan Nowak, stressed in his concept of progress elaborated as a kind of a purposeful social change, an evaluation of change has depended on the value-system developed by a person and/or a group of whom formulated assessments (Nowak 1990). In such a case, an evaluation of modernization depends on Western-type value-systems. In other words, goals of development have been defined by social groups that dominated the reflexivity of society. In the case of modernization, such groups might be synonymous with dominating classes in Western societies. The best example of such a type of thinking has been the contradiction between "the West" and "the rest of the world", where "the West" becomes a major tool of categorization as well as valorization of assessments (Hall 1992). In such a case, some dominating developmental programs as well as an expert knowledge; connected to them, might be treated globally as some important examples of Western culture domination. Therefore, some current theories of development have been pointing out the significance of "local knowledge", both in the stages of formulating, as well as, implementing of developmental projects.

The most important example, contradicting the perspective of social progress based on the Western values, might be found in the dependency theory (see for example: Frank 1969). According to this theory, developmental processes should be perceived as dependent in a structural but not cultural sense. That means that structural relations between more and less advanced societies have been more important than cultural issues of entrepreneurship and agency existing in them. Such a tendency might be observed both in relations between the so-called First and Third World countries, as well as, inside developed societies of Western 
Europe and North America. Poverty and exclusion, in the perspective of dependency theory, have been always resulted from development processes characterized for liberal, or currently neo-liberal, market economy. Such an opinion might be also observed in international developmental projects that have been focused on production and distribution of goods, as well as, services (Mayo 2000: 96). Culture seems to be perceived as a commodity in the neo-liberal perspective of development. However, for South American authors, forming the dependency theory, culture has seemed to be a kind of weapon in the struggle of economic, social and cultural imperialism of the West. In such a sense, culture might be treated as a tool of liberation (see: Pieterse 2010). At the same time, as Mayo stresses, the end of sixties and the beginning of the seventies (in the 20th century) might be treated as a period of emergence of social movements focused on the idea of the so-called "community art" (community arts movements) that has tried to connect "a radical libertarianism with social issues and innovative performances of art" (Mayo 2000: 100). Perceiving structural conditions of underdevelopment and marginalization, these particular movements have used arts as a tool of social contestation, as well as, an instrument of liberation. Thanks to equal right for expression (everybody might be the artist), arts have become forms of participation in public life in the name of various social groups. In other words, arts have been connected to the community empowerments giving their members "the feeling of their own validity, identity, proud and certainty, that might be transferred to other spheres of members ' lives" (Orton 1996: 178; from: Mayo 2000: 115). Basing on such considerations, one might perceive the significance of culture for local developmental processes as revitalization of urban areas both in the First World and Third World countries. Arts-based community development has become a program against cultural, as well as, structural determinism and domination of the West.

Culture might be treated not only as a tool of human empowerment but also as a kind of the autonomous goal of development focused on the fulfillment of post-materialist human needs as well as its self-development, that has been pointed out as a human flourishing (Radwin 1987). In this perspective, human spiritual development seems to be a kind of priority. Moreover, a rich cultural offer becomes a kind of high quality of human life. Culture seems to be a part of basic human rights containing free access 
to cultural values, as well as, participation in the processes of its creation and protection.

Currently, culture has been treated as a factor of economic growth. Cultural capital seems to be treated as a model of production beside the physical, human and natural components. Throsby (Throsby 1999: 6) tries to define the cultural capital as a kind of "cultural value being a part of the resource". Moreover, he stresses out that the cultural capital might be obtained in the form of tangible, as well as, intangible types of human resources. The tangible parts contain buildings, territories, as well as, arts and other parts of material culture (pictures, sculptures), etc. Such resources form the flow of goods and services that might be directly consumed and used as a tool of production of new cultural capital items (Throsby 1999: 7). In turn, the intangible resources: ideas, practices, beliefs, traditions and values form the tools of individual performance and tools of social integration. Moreover, they contain some pieces of arts becoming the "public goods", as for example: literature and music. Such resources become the flows of services and, like tangible ones, have been part of an individual consumption, as well as the production of other cultural goods.

In postmodern societies, the consumption of cultural goods, symbols and pieces of information has increased in a significant way, leading to the development of cultural industry. This process has been named as an emergence of creative industry or creative economy development. In such a perspective, the culture has been treated as a kind of non-sponsored zone. Moreover, culture perceived as a kind of industry, has formed some conditions for creative and innovative practices resulting in an economic growth.

On the other hand, some beliefs, traditions, as well as, cultural values (intangible resources) seem to have a significant impact on the economic system. As Throsby (Throsby 2002: 169) puts it: cultural values seem to be supporting for human development because they frame human behavior in the socio-political, as well as, economic contexts. Therefore, the author concludes that neglecting of intangible cultural capital that equals the destruction of cultural legacy does not support cultural values that might be important for individual identity. Consequently, such a process leads to a total destruction of the cultural system resulting in a fall of economic profitability and a social welfare. 
Moreover, in sociology, culture has been perceived as an instrument of development, as well as, an instrument of production and consumption. On the one hand, inhabitants and tourists might be treated as consuming individuals generating; by their activities, some economic growth. On the other hand, such a process seems to be perceived as a forming of human capital i.e. gathering the creative class that; because of its innovative and creative thinking, leads to the economic development based on knowledge. Evans and Foord (2006) have identified three main groups of individuals who are attracted by such processes in urban communities. The first one has been formed by young and childless people that have discovered many advantages of town life and have focused on the luxury consumption (Zukin 1998). The other group has been formed by tourists interested in cultural, sport, as well as, recreational offers. Moreover, the last group has been formed by the members of the creative class seeking some specific town climate and possibilities for peculiar life styles (Florida 2002, 2005).

Considering some relations between development and culture, it might be treated as a creation of particular type of discourse. In such a sense, the culture itself becomes a kind of discourse that might be analyzed on its own. Researchers, on the basis of their own socio-cultural contexts, prefer various evaluation criteria of social realities. Moreover, particular concepts and developmental projects forming peculiar understandings of culture have been rooted in specific historical conditions. That leads us to the idea of cultural relativism in the frame of developmental studies. Therefore, sociologists have not been convinced about the idea of modernity. Quite contrary, they are convinced about various types of modernities (Wagner 2008). Therefore, the right for "its own way" has been stressed as a kind of strategy consistent with the cultural system of any particular society. In such a case, the culture has been perceived as a kind of identity. All these remarks show us a long way of analysis from early ideas of modernity to various current concepts of modernization.

\section{From a Traditional to a Contemporary Mechanism of Rural Development}

All approaches considering the role of culture in social life, that were pointed out above, might be also connected to the issue of rural development. In this context, we might observe some fundamental changes in developmental 
mechanisms. Our suggestion was to name them as a change from a traditional to a contemporary developmental mechanism. In other words, it might be the move from the idea of rural development based on important changes in agriculture to a more multi-factor type of developmental mechanisms. In the former, the change has been based on the dissemination, as well as, adaptation of new techniques and technologies of agricultural production resulting in major changes of the organization of production and structural changes in farming families and rural communities resulting, in turn, in changes of cultural values and patterns of social behavior (see: Gorlach 2004: 50-85 and 121-160). Quite contrary, the latter mechanism might be characterized by different facets. First of all, in such a multi-factor mechanism, many various issues might be important. Of course, various new techniques and technologies have been still important. However, we do not have in mind the replacing of human by animal forces, neither an introduction of new machines and chemicals, but instead we have to stress the role of bio-technological, as well as, informative (digital) revolution. All these changes lead to the emergence of the so-called industrial agriculture shaping the picture of rural areas in many parts of the contemporary world. The other type of factors of rural change seems to lie in the extensive regulatory processes resulting in the activity of many various social actors. In this context, one should mention that nation-states seem to be among the most important actors. States still form and introduce particular policies including agricultural and rural ones (see for example: Bonnano 2006: 317-329; Goodwin 2006: 304-316). Moreover, such an activity seems to be supported by a large community of various private and public, as well as, local agencies, and extra-local or even global actors forming essential networks in the process of governance (see for example: Murdoch 2006: 171-184; Ray 2006: 278-291). Additionally, one might stress the role of consumption that is becoming more and more important not only because of the existence of farming households but because of the growing number of non-farming individuals and households located in rural areas and consuming various rural resources (see: Salamon 2006: 330-343). Such actors do consume not only food but also other resources like: natural environment, cultural landscape, rural legacy, tradition, etc. resulting not only from the growing agro-tourism movement but also from the growing significance of residential functions of rural areas (see: Miele 2006: 344-354; Crouch 2006: 355-364; Sikora 2012). 
All the issues discussed above lead us to the idea of sustainable development. While in the mainstream discourse, the sustainable development seems to be connected primarily to the idea of natural environment, some other characteristics observed here seem to enlarge the discussion area. Following this line of argument, a particular example of the "sustainable Decalogue" seems to be important (see: Cavanagh and Mander, 2004: 77-102). Such a Decalogue contains important principles of participatory democracy, subsidiary, ecological balance, common legacy, diversity, human rights, protection of the labor market, as well as, the household well-being, food and personal security, and the protection of risk resulting from the global development. It is worth to stress that the above mentioned principles form the value-set contradicting the global tendencies leading to the emerging inequality, poverty and exclusion, as well as, the dictatorship of market forces and transnational corporations. Therefore, rural sustainable development seems to be heavily connected to the idea of the local context and preservation of traditional ways of running farms, both in cultivating crops and raising animals. Moreover, the agency of farmers in local communities, as well as, the rights of rural women and local institutions seem to be also important (see: Elliot 2013: 189-248).

In such a context, cultural factors seem to be important characteristics, especially in the area of legacy, participatory democracy, as well as, diversity. In this particular context, the most important factor seems to be connected to the idea of rural cultural representations that form the area of the public discourse. Many authors offer the statement that social and cultural representations form the important point of reference to the rural developmental programs (see for example: duPuis 2006: 124-132; Short 2006: 133-148; Bell 2006: 149-160). In particular, culture plays the most important role as a frame pointing out developmental paths of rural communities (see for example: Lisocka-Jaegermann 2011). Moreover, culture might form the background and the label of rural production processes. For example, this is, in our opinion, the case of various regional products (see for example: Fonte and Papadopoulos 2010). In turn, culture might form particular cognitive schemes shaping some ways of thinking and acting among the rural population. Therefore, the "local knowledge" forms some important elements of various contemporary developmental projects (see for example: Bruckmeier and Tovey 2009). 


\section{New Type of Rural Development: Some Empirical Evidence from Poland}

Growing cultural diversities in contemporary world result in more complex conceptualizations of universal developmental mechanisms and rules. Therefore, social researchers try to find such mechanisms in regional and/ or local communities, paying more attention to the performance of various social actors. Many contemporary researches have taken the perspective of endogenous or neo-endogenous development as their theoretical frames. One might see the good example of such an idea in the LEADER Programme as a part of Common Agricultural and Rural Policy in European Union since the beginning of the 1990 's. LEADER has become an important part of the Programme of Rural Development in Poland in the years 2007-2013. Its main goal has been focused on the building of social capital through the support for public activity of rural inhabitants, creating of new jobs in rural areas, as well as, improvement of local resource management and valorization of particular local amenities. An important set of actors called Local Action Groups (LGA) has been included in the system of governing such projects called as a system of governance. LGA has been formed by the members of three sectors, namely: public, economic and social ones acting on the basis of prepared Local Development Strategy according to the methods of the LEADER Programme. Such a method has been based on seven basic principles, namely: territoriality, bottom-up initiatives, partnership, making innovations, integrality, cooperation and self-management. Under the LEADER Programme, three main types of activities have been performed, namely: the implementation of local development strategies, implementations of cooperation projects, as well as, functioning of LGA. They have been divided into four operations, such as: a/ diversification of non-agricultural rural economy; b/ creation and development of small enterprises; $c /$ rural renewal and development; $d /$ the co-called: "small projects".

In particular, two last types of operations have used some cultural resources in the process of rural development. In the area of rural renewal and development, as a part of Local Development Strategy, various financial support initiatives for actors creating, remodeling, improving and providing with equipment of various socio-cultural centers, recreational 
and sport facilities have been conducted. Moreover, the local activities and financial support have been focused on the promotion of particular rural communities and landscapes, preservation of their historic, art and culture legacies, renovation and conservation of local historical monuments, "memory places", traditional buildings, preservation of traditional occupations (craftsmanship), etc. Such a support has been channeled to local authorities, cultural centers, local parishes as well as some non-government organizations operating on the Local Action Group territory.

The other type of activity called "small projects" has been even more popular. Majority of initiatives supported under this frame has been focused on the development of local communities, especially the promotion of local culture and tradition based on some local legacies, cultural and natural landscapes, preservation of local customs and habits, local dialects, traditional occupation and crafts. Such a support has been also focused on the development of local cultural centers, renovation of local museums, as well as, rural common rooms. "Small projects" have been addressed to particular individuals, citizens of Poland, living in the area of the LGA activity or doing business in this territory. The second category of "small projects" potential beneficiaries has been formed by informal collective bodies or associations that attained the formal legal status and operating in this territory.

Rural Poland has gone through the deep and complex changes in last twenty years (see for example: Rosner 2012a; 2012b; Drygas and Zawalińska 2012; Bukraba-Rylska and Burszta 2011; Wilkin and Nurzyńska 2012). We have to stress here; especially, the considerations by Jerzy Wilkin, one of the most outstanding contemporary Polish agricultural economists trying to recapitulate significant changes in rural areas in last twenty years (Wilkin 2012: 23). He has identified eight basic tendencies characterizing the situation of rural Poland under the new democratic regime and market economy. Firstly, only 70 percent of rural inhabitants has some "rural roots" in the first, second or third generations. Moreover, this percentage decreased in the last twenty years. Secondly, 39.1 percent of the population of Poland lives now in rural areas, but; quite recently, we might observe the increase of this proportion. Thirdly, slightly less than 13 percent of the workforce has been employed in agriculture and the decrease tendency has been observed here. Fourthly, less than 50 percent of rural population has 
been involved in farming, and; again, we might observe decline tendency here. Fifthly, agricultural production has contributed as 3 percent of GDP in Poland and declines. Sixthly; however, agro-food export of Poland has formed roughly 10 percent of the total export and remains relatively stable. Seventhly, one might also observe that the incomes from farming have formed only 15 percent of total incomes among rural population and constantly decline. Finally, arable land covers almost 50 percent of total land area in Poland. But this percentage has been also declining in the last twenty years.

All the tendencies mentioned above show the nature of rural change in Poland after 1989, focused; first of all, on multifunctional development. At the same time, more goods and services produced in agriculture and, more generally, in rural economy have not been pure of market character. Rural inhabitants have been gradually perceived not only as producers of agricultural commodities but also the "guards" of rural space and nature, and providers of tourist services (agro-tourism) (Wilkin, 2012: 36). Moreover, some other researchers show the role of EU regional policies in the processes of rural changes in Poland. Monika Stanny (Stanny 2012: 172-173) stresses rather relatively ambivalent effects of such policies in the process of overcoming of historically established socio-economic discrepancies among various regions in Poland. Based on the index constructed by her, she came to the conclusion that the most important factor of rural development has been connected to local and regional multifunctional economic centers. They form the so-called endogenous factors of change responsible for the rating of local communities (gminas). On the other hand, the most important exogenous factor responsible for this rating has been connected, according to Stanny, to historical processes of modernization taken place in the 19th century Poland during the period of partitions. Economic policies taken by the Russian, German and AustroHungarian empires in late 19th and early 20th centuries still matter. That means that culture perceived in this case as a kind of historical legacy still plays the role in the process of comparing advantages and disadvantages of particular regions and even localities in contemporary Poland (see also the same author: Stanny 2013).

De-agrarisation processes might be observed not only in occupational structure of rural communities but also in other dimensions of social life. Many changes might be pointed out in rural economies, architecture, 
landscape, social relations and ways of life, including leisure time. New institutions and facilities such as: fitness clubs, swimming pools, beauty salons and exercise rooms have become visible. Leisure time, the idea almost unknown and; to some extent, even immoral among former and older rural inhabitants, has become quite common and familiar to contemporary rural dwellers who have mostly not been farmers. The way of spending of leisure time has become now also a kind of distinction among rural population much as among social elite members in previous times. Prestige among rural dwellers has been based currently also on the way of free time spending. Work (including farm work) has lost its privileged and exceptional role in defining social positions in rural communities.

Free time spending in contemporary rural communities has been connected with the processes of cultural consumption among rural inhabitants. Recent research done by social anthropologists and ethnographers in Poland has shown that such cultural consumption has been mainly based on personal experience and a kind of a "total" participation in such events. As Bukraba-Rylska (Bukraba-Rylska 2012: 140) stresses, cultural consumption and cultural practices of rural inhabitants have been based mainly rather on unconscious behavioral scripts than consciously formed and persuasively articulated and communicated narratives. Contemporary rural culture and consumption in rural communities have been based on the idea of "festivities" (Bukraba-Rylska and Burszta 2011). Such a culture has been based on three important factors, namely: its "openness" (such events are performed in public space and all members of particular community are invited to participate); its multi-sensuality (that has been connected to the total type of participation mentioned above), and short-term, as well as, superficial character of emerging social relations (Bukraba-Rylska 2012: 135-137).

In contemporary approaches to sustainable development, some local factors, resources and conditions have been especially stressed (see for example: Elliott 2013). In such a context, the role of various local actors including; especially, members of local elites, has to be also emphasized. The heads of local authorities, local representatives of particular village communities, local school masters and leading farmers should be included in this category. Moreover, local parish priests, doctors in local health centers, members of local councils, and even professional politicians might also be treated as members of the categories under consideration. However, 
their role seems to decline in recent years (see for example: Nowak 2012). Therefore, opinions of heads of local authorities, representatives of village communities, school masters and leading farmers concerning key issues of local development seem to be of primary importance. They have been key actors of local political, cultural and business milieu. Their opinions on local development might be treated as a part of the process of social construction of local change and; therefore, in such a context, they might be perceived as a kind of local cultural resources having an impact on social processes in investigated communities (see more: Nowak 2012). Their opinions on key factors of rural development are presented in the table below.

Tab. 1. Opinions of members of rural elites concerning factors having an impact on local development (in \%)

\begin{tabular}{|l|c|c|c|c|c|}
\hline $\begin{array}{c}\text { Three the most } \\
\text { important issues on } \\
\text { rural development }\end{array}$ & Total & $\begin{array}{c}\text { Hades } \\
\text { of Local } \\
\text { Authorities }\end{array}$ & $\begin{array}{c}\text { Represtatives } \\
\text { of village } \\
\text { communities }\end{array}$ & $\begin{array}{c}\text { School } \\
\text { Masters }\end{array}$ & Farmers \\
\hline Social capital & 49,6 & 48,4 & 40,6 & 68,2 & 40,7 \\
\hline Geographical location & 28,7 & 40,9 & 18,2 & 27,5 & 28,2 \\
\hline Economic conditions & 27,9 & 23,9 & 26,3 & 27,5 & 33,9 \\
\hline Economic capital & 25,7 & 35,2 & 27,5 & 23,8 & 16,3 \\
\hline $\begin{array}{l}\text { Management and } \\
\text { administration }\end{array}$ & 25,2 & 20,8 & 32,6 & 35,0 & 31,3 \\
\hline Infrastructure & 24,0 & 25,8 & 23,2 & 23,8 & 23,2 \\
\hline External Funds & 15,7 & 15,7 & 18,2 & 15,7 & 13,1 \\
\hline Historical Amenities & 13,3 & 15,1 & 15,1 & 10,6 & 12,5 \\
\hline $\begin{array}{l}\text { Cultural and } \\
\text { Educational Activities }\end{array}$ & 9,1 & 5,7 & 13,2 & 12,5 & 5,0 \\
\hline & 4,4 & 9,4 & 3,2 & 3,8 & 1,3 \\
\hline
\end{tabular}

Source: Nowak (2012)

According to their opinions, the social capital seems to be the most important factor of development. Moreover, all respondents stressed both endogenous and exogenous factors in this context. Ten percent among them stressed also purely cultural factors, such as various cultural and educational 
activities. They emphasized the role of material and non-material cultural elements, such as monuments, museums, open air museums and local customs and habits as important resources that might be exchanged to other types of capital that might improve the standard of living among local population. The heads of local authorities; during in-depth interviews, stressed the need for searching of important and valuable internal resources that later might be strengthened with particular external factors, like external financial support, technical infrastructure, and also cultural ones. Lastly, some external types of knowledge such as expert/scientific, as well as, managerial ones were pointed out as important factors shaping local development and improvements of local conditions of living.

Moreover, it should be stressed that significant differences in opinions between various categories of respondents might be observed. School masters and representatives of village communities; more often than other categories, stressed the role of cultural resources. In turn, one might perceive some similarities between heads of local authorities and farmers. Both groups seemed to think in an economic way about changes in social life. For them, something has been important mainly if it can be presented exactly in an accountable way, just as it has been conceptualized as the formal rationality scheme presented in the classic study by Max Weber (Weber 2002). To some extent, both these groups behave like businessmen or even financial officers focused on the pure economic growth and profit. It also should be stressed that in the previous research conducted in the same local rural communities but only among heads of local authorities ( $45 \%$ of them kept their offices and were investigated in 2012) there were no answers about the importance of cultural resources and educational factors in the processes of local rural development. It seems that because of the European integration, stronger mobility of rural inhabitants, as well as, new public policies stimulated by EU programmes, cultural factors and resources have become more important factors of human development. LEADER programme, mentioned above, seems to be a good example of such a policy that has been based on the ideas of neo-endogenous development (see: Ray 2006).

Investigated members of local rural elites were also asked about the most constraining factors that shape; in a negative way, human development of their communities. Some results are also presented in table 2 below. According to them, the shortage of financial resources and a bad economic 
situation in the region or in the whole country, as well as, the low level of technical infrastructure have played the most negative role in the development. Moreover, more than $20 \%$ of respondents have pointed out the low level of social capital and unfavorable geographical location in this context. Finally, only less than $5 \%$ of respondents stressed the negative role of cultural resources in the processes of local development. It should be also emphasized that the average level of local budget spending focused on protection of local historical legacies has reached roughly $5 \%$. However, it has been diversified as well. Some communities have spent less than $1 \%$ (!), while others even more than $10 \%$.

Tab. 2. Members of local rural elites concerning the factors hindering the local development

\begin{tabular}{|l|c|}
\hline \multicolumn{1}{|c|}{$\begin{array}{c}\text { What are the three most important factors } \\
\text { of braking of the local development }\end{array}$} & Total: (in \%) \\
\hline Low level of economic capital & 54.0 \\
\hline Economic conditions & 35.5 \\
\hline Lack of technical infrastructure & 23.6 \\
\hline Low level of social capital & 21.1 \\
\hline Unfavorable geographical location & 19.6 \\
\hline Culture & 4.5 \\
\hline
\end{tabular}

Source: Nowak (2012).

\section{Conclusions}

The main message of our consideration was focused on the role of culture factors in the context of sustainable development. Culture was perceived here as a relatively autonomous factor having various impacts on economic and political processes as it was stressed in the cultural turn perspective. The authors pointed out twelve various understandings of culture and its role in the processes of human and social development. These were namely: culture as legacy, culture as modernity, culture as an instrument of modernization, culture as a developmental type of resource; culture as politics, culture as a mechanism of economic growth, culture as industry, 
culture as power, culture as an instrument for human emancipation and agency, culture as a type of human rights, culture as identity, as well as, culture as discourse.

Following discussion focused on some various understandings of culture in the context of development - the authors discussed selected issues concerning rural development. The "new" mechanism of rural development was stressed, containing three main characteristics. The multi-factor characteristic based on the assumption that many factors have an impact on changing society was indicated as a first one. Moreover, it was emphasized that rural development results from activities of various networks consisting of different actors representing global, national, as well as, local forces and interests. Finally, culture and consumption were considered as important parts of neo-endogenous development mechanism. More general considerations were supported by some selected analyses by various Polish authors on the role of cultural legacies and resources in contemporary rural development in Poland. Moreover, some selected results of empirical research focused on roles of local actors in local rural development, showing the role of cultural resources perceived by members of rural local elites as a new type of advantages in the processes of social change, were explored.

\section{Literature}

Bell, D., 2006. Variations on the rural idyll. In: Cloke, P., Marsden, T. and Mooney P. (eds.) Handbook of Rural Studies, London-Thousand Oaks-New Delhi: SAGE Publications, pp. 149-160.

Bonnano, A., 2006. The state and rural polity. In: Cloke, P., Marsden, T. and Mooney P. (eds.) Handbook of Rural Studies, London-Thousand Oaks-New Delhi: SAGE Publications, pp. 317-329.

Bradley A., Hall T., 2006. The Festival Phenomenon. Festivals, Events and the Promotion of Small Urban Areas. In: Bell, D. and Jayne M. (eds) Small Cities: Urban Experience beyond the Metropolis, Oxon: Routledge.

Bruckmeier, K., Tovey, H. (eds.), 2009. Rural Sustainable Development in the Knowledge Society, Aldershot: Ashgate.

Bukraba-Rylska, I., Burszta, W., 2011. Stan i zróżnicowanie kultury wsi i małych miast w Polsce, Warszawa: Narodowe Centrum Kultury. 
Bukraba-Rylska, I., 2012. Kultura na wsi: folklor, uczestnictwo czy praktyki kulturowe. In: Rosner, A. Społeczne i kulturowe zagadnienia przemian na wsi polskiej, Warszawa: Instytut Rozwoju Wsi i Rolnictwa PAN, pp. 119-145.

Cavanagh, J., Mander, J. (eds.), 2004. Alternatives to Economic Globalization, San Francisco: Berrett-Koehler Publishers, (second and enlarged edition).

Crouch, D., 2006. Tourism, consumption and rurality. In: Cloke, P., Marsden, T. and Mooney P. (eds.) Handbook of Rural Studies, London-Thousand Oaks-New Delhi: SAGE Publications, pp. 355-364.

Drygas, M., Zawalińska, K. (eds.), 2012. Uwarunkowania ekonomiczne polityki rozwoju polskiej wsi i rolnictwa, Warszawa: Instytut Rozwoju Wsi i Rolnictwa PAN.

DuPuis, M., 2006. Landscapes of desires?. In: Cloke, P., Marsden, T., Mooney P. (eds.) Handbook of Rural Studies, London-Thousand Oaks-New Delhi: SAGE Publications, p. 124-132.

Elliot, J. A., 2013. An Introduction to Sustainable Development, London and New York: Routledge (fourth edition).

Evans, G., Foord, J., 2006. Small cities for a small country: sustaining the cultural renaissance? In: Bell, D., Jayne M. (eds.), Small Cities: Urban Experience beyond the Metropolis, Oxon: Routledge.

Florida, R., 2002. The Rise of the Creative Class, New York: Basic Books.

Florida, R,. 2005. Cities and the Creative Class, New York: Routledge.

Fonte, M., Papadopoulos, A. (eds.), 2010. Naming Food after Places. Food Relocalisation and Knowledge Dynamics in Rural Development, Aldershot: Ashgate.

Frank, A. G., 1969. Latin America: Underdevelopment or Revolution, New York: Monthly Review Press.

Goodwin, M., 2006. Regulating rurality? Rural studies and the regulation approach. In: Cloke, P., Marsden, T., Mooney P. (eds.) Handbook of Rural Studies, London-Thousand Oaks-New Delhi: SAGE Publications, pp. 304-316.

Gorlach, K., 2004. Socjologia obszarów wiejskich. Problemy i perspektywy, Warszawa: Wydawnictwo Naukowe SCHOLAR.

Granovetter, M., 1985. 'Economic action and social structure. The problem of embeddness', American Journal of Sociology, Vol. 3 (91): 481-510.

Hall, S., 1992. The West and the rest: discourse and power. In: Hall, S., Gieben, B. (eds.) Formations of Modernity, Cambridge: Polity Press.

Klekotko, M. (2012) Rozwój po śląsk: procesy kapitalizacji kultury w ślaskiej społeczności górniczej, Wydawnictwo Uniwersytetu Jagiellońskiego, Kraków. 
Kłoskowska, A., 1983. Socjologia kultury, Warszawa: Państwowe Wydawnictwo Naukowe (second edition).

Krzysztofek, K., Szczepański, M. S., 2002. Zrozumieć rozwój. Od społeczeństw tradycyjnych do informacyjnych, Katowice: Wydawnictwo Uniwersytetu Śląskiego.

Lisocka-Jaegermann, B., 2011. Kultura w rozwoju lokalnym. Dziedzictwo kulturowe $w$ strategiach społeczno-gospodarczych latynoamerykańskich społecznosci wiejskich, Warszawa: Wydawnictwa Uniwersytetu Warszawskiego.

Mayo, M., 2000. Cultures, Communities, Identities. Cultural Strategies for Participation and Empowerment, Hampshire: Palgrave Macmillan.

Miele, M., 2006. Consumption culture: the case of food. In: Cloke, P., Marsden, T., Mooney P. (eds.) Handbook of Rural Studies, London-Thousand Oaks-New Delhi: SAGE Publications, pp. 344-354.

Murdoch, J., 2006. Networking rurality: emergent complexity in the countryside. In: Cloke, P., Marsden, T., Mooney P. (eds.) Handbook of Rural Studies, LondonThousand Oaks-New Delhi: SAGE Publications, pp. 171-184.

Nowak, P., 2012. Rozwój obszarów wiejskich w Polsce po integracji z Unia Europejska w opinii lokalnych elit, Wydawnictwo Uniwersytetu Jagiellońskiego.

Nowak, S., 1990. Models of Directional Change and Human Values. The Theory of Progress as an Applied Social Science. In: Alexander, J. C., Sztompka P. (eds.) Rethinking Progress. Movements. Forces, and Ideas at the End of the 20th Century, Boston: Unwin Hyman.

Ogburn, W., 1975. Hipoteza opóźnienia kulturowego. In: Derczyński, W., JasińskaKania, A., Szacki J. (eds) Elementy teorii socjologicznych, Warszawa: Państwowe Wydawnictwo Naukowe, pp. 255-261.

Pieterse, J. N., 2010. Development Theory, London-Thousand Oaks-New DelhiSingapure: SAGE Publications.

Radin, M. J., 1987. 'Market Inalienability', Harvard Law Review, Vol. 100 (8): 1848-1937.

Ray, Ch., 2006. Neo-endogenous rural development in the EU, In: Cloke, P., Marsden, T., Mooney P. (eds.) Handbook of Rural Studies, London-Thousand OaksNew Delhi: SAGE Publications, pp. 278-191.

Ray, L.; Sayer, A. 1999 (eds.), Culture and Economy after Cultural Turn, London - Thousand Oaks - New Delhi: SAGE Publications.

Rosner, A. 2012a (ed.), Rozwój wsi i rolnictwa w Polsce, Warszawa: Instytut Rozwoju Wsi i Rolnictwa PAN. 
Rosner, A. 2012b (ed.), Społeczne i kulturowe zagadnienia przemian na wsi polskiej, Warszawa: Instytut Rozwoju Wsi i Rolnictwa PAN.

Rostow, W.W., 1960. The Stages of Economic Growth: A Non-Communist Manifesto, Cambridge: Cambridge University Press.

Salamon, S., 2006. The rural household as a consumption site. In: Cloke, P., Marsden, T., Mooney, P. (eds.) Handbook of Rural Studies, London-Thousand OaksNew Delhi: SAGE Publications, pp. 330-343.

Short, B., 2006. Idyllic ruralities. In: Cloke, P., Marsden, T., Mooney, P. (eds.) Handbook of Rural Studies, London-Thousand Oaks-New Delhi: SAGE Publications, pp. 133-148.

Sikora, J., 2012. Agroturystyka. Przedsiębiorczość na obszarach wiejskich, Warszawa: C. H. Beck.

Shaw, S., Bagwell S., Karmowska, J., 2004. 'Ethnospaces as spectacle: reimaging multicultural districts as New destinations for leisure and tourism', Urban Studies, 41 (10): 1983-2000.

Stanny, M., 2012. Społeczno-ekonomiczne zróżnicowanie obszarów wiejskich. In: Wilkin, J.; Murzyńska J. (eds.) Polska wieś 2012, Warszawa: Wydawnictwo Naukowe SCHOLAR, pp. 149-174.

Stanny, M., 2013. Przestrzenne zróżnicowanie rozwoju obszarów wiejskich w Polsce, Warszawa: Wydawnictwo Instytutu Rozwoju Wsi i Rolnictwa PAN.

Symonides, J., 1998. 'Cultural rights: A neglected category of human rights', International Social Science Journal, Vol. 158: 559, 14p, 2bw (Webpage: http:// www.iupui.edu/ anthkb/a104/humanrights/cultrights.htm).

Świątkiewicz, W., 2000. Wokót socjologicznej koncepcji kapitału społecznego. In: Szczepański M. S. (ed.) Kapitał społeczno-kulturowy a rozwój lokalny i regionalny, Tychy: Śląskie Wydawnictwa Naukowe.

Throsby, D., 1999. 'Cultural Capital', Journal of Cultural Economics, Vol. 23: 3-12.

Throsby, D., 2002. Cultural Capital. In: Towse, R. (ed.) A Handbook of Cultural Economics, Glos-Masachusetts: Edward Elgar Publishing.

Wagner, P., (2008), Modernity as Experience and Interpretation. A New Sociology of Modernity, Cambridge: Polity Press.

Weber, M., 1994. Etyka protestancka a duch kapitalizmu, translated into Polish by Jan Miziński, Lublin: Wydawnictwo Test.

Weber, M., 2002. Gospodarka i społeczeństwo. Zarys socjologii rozumiejacej, Warszawa: Wydawnictwo Naukowe PWN. 
Wilkin, J., 2012. Wieś i rolnictwo w strukturach współczesnej Polski. In: Drygas, M., Zawalińska, K. (eds.) Uwarunkowania ekonomiczne polityki rozwoju polskiej wsi i rolnictwa, Warszawa: Instytut Rozwoju Wsi i Rolnictwa PAN, pp. 19-39. Wilkin, J, Murzyńska, I., (eds.), 2012. Polska wieś 2012, Warszawa: Wydawnictwo Naukowe SCHOLAR.

Zukin, S., 1998. 'Urban Lifestyles: diversity and standarisation in spaces of consumption', Urban Studies, Vol. 35 (1): 825-839. 